\title{
Community empowerments strategy for economic opportunities in Selayar Islands Regency, South Sulawesi
}

\section{Strategi pemberdayaan masyarakat untuk peluang ekonomi di Kabupaten Kepulauan Selayar, Sulawesi Selatan}

\author{
Ilham Junaid \\ Department of Tourism Management, Politeknik Pariwisata Makassar \\ Address: Jalan Gunung Rinjani, Tamalate, Makassar, South Sulawesi, Indonesia 90224 \\ E-mail: illank77@yahoo.co.id
}

Article History: Received 6 September 2019; Accepted 19 January 2021; Published Online 16 February 2021

\begin{abstract}
Indonesia is an archipelagic state with considerable potential as tourism destinations, yet that potential has not been fully maximized. This paper aims to examine the opportunity and potential of Gusung Island as tourism resources and propose possible strategies to manage the tourism resources of Gusung Island, Selayar Islands Regency. The research was conducted in July and August 2019 on Gusung Island, Selayar Islands Regency, South Sulawesi Province by applying qualitative research methods. Methods of data collection are through in-depth interviews with the fishing community and their families, direct observation or observation in Gusung Island, and focused discussions held in Benteng City, Selayar Islands Regency. The research reveals that marine tourism and local community activities have a considerable potential to support Gusung Island as a tourism destination. Strategies for community empowerment include educating and facilitating community for hospitality skills, creating tourism packages by involving the tourism industry and the local community, strengthening the working group's role in managing the tourism resources of Gusung Island. Sustainable tourism may be booming if the local community organizations play a pivotal role in facilitating the local community to preserve the environment.
\end{abstract}

Keywords: community empowerment; tourism; economic opportunity

\begin{abstract}
Abstrak
Indonesia memiliki pulau-pulau yang memiliki potensi wisata tetapi belum dimaksimalkan menjadi daerah atau destinasi wisata. Tujuan penelitian ini adalah untuk mengkaji peluang dan potensi Pulau Gusung (sumber daya pariwisata) sebagai destinasi wisata dan untuk mengusulkan strategi pemberdayaan masyarakat dalam mengembangkan potensi pariwisata. Penelitian dilaksanakan pada bulan Juli dan Agustus tahun 2019 di Pulau Gusung, Kabupaten Kepulauan Selayar, Provinsi Sulawesi Selatan dengan menerapkan metode penelitian kualitatif. Metode pengumpulan data melalui wawancara mendalam dengan masyarakat nelayan beserta keluarganya, observasi atau pengamatan langsung ke Pulau Gusung dan diskusi terarah yang dilaksanakan di Kota Benteng, Kabupaten Kepulauan Selayar. Hasil penelitian menunjukkan bahwa wisata bahari dan aktifitas kehidupan masyarakat Pulau Gusung yang alamiah dapat menjadi daya tarik bagi wisatawan untuk berkunjung, hal ini berarti bahwa Pulau Gusung sangat potensial. Pemberdayaan masyarakat dapat ditempuh dengan mengoptimalkan tiga strategi yakni edukasi masyarakat dan pendampingan keterampilan keramahan (hospitality), pembuatan paket wisata dengan melibatkan industri pariwisata, pengemasan dan implementasi pemasaran potensi wisata, serta pentingnya mendorong peran kelompok kerja masyarakat atau lembaga masyarakat untuk mendorong implementasi pariwisata berkelanjutan.
\end{abstract}

Kata kunci: pemberdayaan masyarakat; pariwisata; peluang ekonomi

\section{Introduction}

Tourism has emerged as a promising activity to uncover the potential of a community, and it allows people to observe the culture or habits of a community group. The tendency for tourists to observe the local community's behavior in their destination makes tourism a strategic bridge of interaction between tourists and the local people. On the other hand, the local community expects a positive impact from tourists who visit their area. Community tourism could have two impacts on the affected group. Firstly, the local community will receive benefits from tourism, or, secondly, the local community will receive a lack of impact of tourism activity in their area. 
Given the phenomenon, a growing number of studies have discussed how the community reacts or responds to tourism activities. Different parts of society have different views about tourism, including when tourists come to their area. The lack of understanding about tourism's meaning shows a high need to educate the local people about tourism. Conversely, if the community has understood the meaning or benefits of tourism, the proper response is to manage the existing potential through community empowerment. People who have tourism potential need to be empowered, considering that they expect a positive impact from tourism activities (Agrusa \& Albieri 2011, Jurowski 2011, Moscardo 2008). Therefore, they can optimize available opportunities for the benefit of the community in the tourism area.

People who live on islands tend to lack understanding of their potential. There is limited understanding of tourism, which hinders them from maximizing their true potential, as is the case shown in Gusung Island, an island near the Benteng City, Selayar Islands Regency, South Sulawesi Province. Selayar Islands Regency has scattered islands, namely Gusung Island, about ten minutes by boat from Benteng City. A visit to this area illustrates that there is a need for community empowerment efforts regarding their potential. Ideally, tourist arrivals perceive as beneficial opportunities that require adequate planning and implementing services to tourists; however, community members are less responsive in developing tourism because of their inability to participate in tourism activities.

Even though Gusung Island is located relatively near to Benteng, the island can be the primary choice for tourists, especially those who like culture, and nature community-based tourism of people on an island. The island offers natural attractions and rural ambiance; hence tourists' presence is expected to provide positive values for the community. Therefore, community empowerment is one of the alternatives to improve community welfare through tourism activities. According to Richards \& Hall (2000), not all local community members benefit equally from tourism development in an area. It is why empowerment is an essential aspect if an area opens as a tourist destination. Empowerment is needed because people who have the potential for human and natural resources need to be developed to benefit the community.

This research is to study the economic opportunities and tourism potential of Gusung Island and describe the community empowerment strategy in developing the existing potential for the benefit of the community. Following this study's objectives, the research problems formulated are: 1) What are the economic opportunities and potentials of Gusung Island people in the tourism sector? 2) What is the strategy for empowering Gusung Island people in utilizing the tourism potential of the island? Discussion about society has become an exciting study given its role as subject and object of a program. In tourism studies, the concept of society has been widely studied by various academics. One of the publications that examine the society in the context of tourism is by Murphy (1985), according to whom the community approach and ecological approach need to be balanced to achieve sustainability and a balance between the community and the environment in the planning and policy process for tourism development.

Community empowerment is an implementation or a manifestation of community participation or involvement in tourism activities. Hall (2000) suggests four reasons for the island communities' empowerment. First, empowerment is a process where the community is involved in decisionmaking, directly affecting the community. Second, empowerment is an effort to support environmental conservation and community resource protection (Martono \& Muhamad 2017, Strzelecka \& Wicks 2013, Yulianie 2015). Kusumawardani \& Septiarti (2019) suggest that empowerment for the young generation in areas or rural areas needs sufficient planning to preserve their natural and cultural potential. Third, community involvement is an effort also to involve the tourism industry, which provides services to tourists. Fourth, tourist satisfaction resulted from a positive response from the community through their involvement in tourism activities. This research suggests that community empowerment programs are needed to help capacitate people who have tourism potential. Martono \& Muhamad (2017), in Penglipuran Tourism Village, Bali, shows that community empowerment can bridge the preservation of community socio-cultural values. 
There are two approaches in community empowerment efforts, namely the bottom-up and a top-down approach. The bottom-up approach means that all decisions, programs, or plans are planned and decided upon by the community. A top-down approach means that a program is planned at the top level (government) before disseminating it to the community. Ideally, the bottom-up approach is a preferred option, and this community can be managed optimally for their benefit. As the top-level policy maker (top), the government carries out the community's mandate by regional development goals. These two approaches can also be combined with integrating implementation between bottom-up and topdown by maximizing various stakeholders' roles in a tourist destination (Clarke \& Raffay 2011).

The community has become an inseparable part of tourism due to its vital involvement in tourism development, planning, and management (Junaid \& Nur Fauziah 2018, Obenour \& Cooper 2013, Richards \& Hall 2000, Rocharungsat 2008, Syafi'i \& Suwandono 2015). In several cases, the community has become the base reason for a project or plan to develop a new tourist destination. An area that has tourism resources will always involve the community as an essential part of a destination. In some tourist destinations, the community is also one reason an area is promoted as a tourist destination. In this case, the community can become a tourist attraction, so that its existence is one of the prerequisites for the realization of tourism activities.

Dahles (2000) examines tourism and society in Indonesia in the context of small-scale tourism businesses. According to Dahles (2000), the Indonesian government has encouraged the management of small businesses by the community because these can be a forerunner to increase larger businesses. Small businesses managed by the community cannot be separated from the community built by the community either because of kinship or friendship. Maintaining small businesses by the community requires income security by the community, insurance or protection, marketing (including advertising), and information. With this approach, the community can be involved in maintaining their businesses to market their services.

An area can be developed based on rural tourism principles (Mertha et al. 2018, Priyanto \& Safitri 2016, Putra 2013, Ratu \& Adikampana 2016). On an island, a group of people lives together, which regulate in a village regulation. Thus, it can be said that a tourist village can be a strategy for developing the island's potential. According to Callders (2000), three links need to be applied to build a tourism village: the relations in the tourism sector through product development and marketing approaches, the relations between the tourism sector and other sectors, and relations with the outside world for innovation and market knowledge. These three relations indicate that an inseparable relationship is a prerequisite from community groups to create a tourist village.

\section{Research Method}

This research results from a visit to Selayar Islands Regency, South Sulawesi Province in July and August 2019, including visiting Gusung Island for research purposes. Qualitative research with a descriptive approach guides researcher in digging up information and looking for research data related to the research topic. The main focus of data collection in this research is what and how is the current condition of the people on Gusung Island, especially regarding tourism potential, might be a force in community empowerment through tourism. Qualitative research methods allow researcher to describe society's social conditions from research informants' perspective (Hesse-Biber \& Leavy 2011, Riley \& Love 2000, Yin 2011). In this case, the informants involved in this research are people who live on Gusung Island.

The study collected data through interviews, focused group discussion, and observation. Researcher conducted interviews with community members on Gusung Island (North Gusung, West Gusung, and Gusung Lengu) consisting of five fishers and six community members living in the area. The interview duration depended on the informants' availability, generally lasting around 30-40 minutes. The interview focused on daily activities, community expectations, and issues related to people's understanding of tourism. Furthermore, the observation was carried out when the researcher visited Gusung Island. Researcher also made a record by looking at the actual conditions in the field. The main focus of observation is community activities and natural landscape owned by the community that can become tourism potential. 
A focus group discussion was carried out to support the search for information from people in Benteng City, Selayar Islands Regency. It provides information about Gusung Island people's expectations regarding managing their natural and cultural potential through tourism activities. The informants involved in this study were based on their willingness to provide information to researcher. This research was conducted after obtaining permission from the village government. The research stages were carried out in four stages; first, the researcher made an initial visit to Gusung Island; in this visit, researcher asked permission from the local government through the head of the village. The visit to Gusung Island collected data through observation and interviews; second, the researcher communicated with the Selayar Islands Regency's tourism office to implement a focus-group discussion in Benteng City to ensure that the community members of Gusung Island were involved in the focus group discussion. Third, the second visit to Selayar Islands Regency was conducting research, especially focus-group discussion activities. Fourth, focus-group discussion activities were carried out with the participation of members of the Gusung Island community.

The qualitative data obtained were analyzed using the data reduction process, namely the classification and presentation of data and data interpretation. In this process, the researcher applies a thematic analysis approach, looking for essential information in qualitative data by identifying, analyzing, and reporting the data in the form of meaning interpretation (Altinay \& Paraskevas 2008, Junaid 2016). Researcher listened to information from informants and recorded essential data related to the research objectives. Furthermore, researcher recorded and linked this information with other qualitative data. The data analyzed were information from interviews, focus group discussions, and field notes during direct observation. These data are described by writing the research results by applying the interpretation of the data's meaning. The process of meaning interpretation is dedicated to answer the research problems and achieve the research objectives.

\section{Result and Discussion}

\section{The overview of Gusung Island}

Gusung Island is one of the Selayar Islands Regency with three regional divisions: East Gusung, West Gusung, and Gusung Lengu. Gusung Island locates in Bontoharu District, Bontolebang Village, approximately one mile away or about 15 minutes by sea. Gusung Island can be reached via the port in Benteng City by traditional boats, either with a boat rental system or together with the people about the cross to Gusung Island. To reach Gusung Island by traditional boat, visitors must ensure that they have an opportunity to return to Benteng City. The total population of Bontolebang Village is 1.005 people consisting of 310 people in West Gusung, 328 in East Gusung, and 367 people in Gusung Lengu (Table 1).

Table 1.

Total population of Bontolebang Village

\begin{tabular}{|c|c|c|c|c|}
\hline \multirow{2}{*}{ Village } & \multicolumn{4}{|c|}{ Total population (June 2019) } \\
\hline & Male & Female & Amount & Total household \\
\hline West Gusung & 157 & 153 & 310 & 87 \\
\hline East Gusung & 175 & 153 & 328 & 88 \\
\hline Gusung Lengu & 193 & 174 & 367 & 101 \\
\hline Total & 525 & 480 & 1005 & 276 \\
\hline
\end{tabular}

The researcher recorded that guests who visit Gusung Island need to be given clear information about the transportation required and how to return to Benteng City. Researcher had to ask the people in Benteng City several times to ensure that the boat to be boarded was destined for Gusung Island. In addition, visitors may have difficulty obtaining information about the departure schedule given that it is not clear when the community or the boat will depart. Even though the distance is quite close from Benteng City, guests going to Gusung Island must seek clear information about the crossing method's destination and the transportation to be used. 
When researcher visited Gusung Island, they found the high tides only allow people to reach and depart from the island in the morning. Thus, it was easier for people to moor their boats on the Gusung Island coast in the morning. In the afternoon, people have to find a location or position to tie their boats or to transport passengers because the water recedes. Such a situation needs to be understood by Gusung Island tourists. Visits to Gusung Island directly provide information to researcher about tourism opportunities and attract foreign and domestic tourists. The following describes opportunities that can be the reasons for the development of tourism in Gusung Island and the empowerment of people who live in the region.

Geographically, Gusung Island is the area or island closest to Benteng City. It takes ten minutes to cross the sea and reach the island by traditional boat. One of the reasons for most tourists to visit the area is the close distance between the city and the island and that it takes little time to travel between them. Gusung Island's strategic location has fulfilled the expectations and needs of visitors regarding the travel mileage. Therefore, Gusung Island deserves to be promoted as a tourist destination and a marine tourism attraction in Selayar Regency. Traditional boats owned by the community can be an opportunity to be used as a mode of transportation for tourists either coming to Gusung Island or for island exploration. The local government (including the village government) is trying to develop tourism. In addition, people do not object to tourism development, primarily if tourism provides economic value to local communities. It is an opportunity for the community to improve their economy apart from being a daily fisherman. Community hospitality is also an opportunity for tourism development on Gusung Island, and researcher received good service from the local people. We responded positively to efforts and opportunities to make Gusung Island a leading tourist destination in Selayar Regency.

\section{Tourism potential and community empowerment of Gusung Island}

Gusung Island possesses natural and cultural resources that can be an influential attraction for tourists to visit. First, the traditional community's life on Gusung island is potential for cultural tourism, marine tourism, and marine tourism-based tourism villages. Traditional houses and traditional community activities are valuable to attract tourists to visit Gusung Island. Fishermen's daily routines also hold a tourism potential in the aspect of locals' traditional activities. The tourism potential can be added in a marine tourism package where visitors can learn about the community's marine life. A majority of tourists were attracted to experience the traditional activities of a community. Therefore, this potential needs to be managed as a tourism potential that can provide added value for the community.

The second tourism attraction of the island is a mangrove area located in East Gusung. Although currently, mangrove management needs to be widely improved, mangrove tourism with the principle of marine ecotourism can be a remarkable way to promote tourism in Gusung Island. Our observation showed that mangroves had been visited by several tourists even though the numbers are low. Visitors are still limited because of its location on an island outside Benteng City. Third, the people of Gusung Island's skills in making traditional cuisine can be an added value and a tourism potential. From the results of the interviews, there were community members who had made and sold traditional cakes that could be sold to tourists.

Fourth, Gusung Island is in the middle of the sea with a coastal area with beautiful white sand and a stretch of sea with remarkable scenery. Gusung Island offers a village atmosphere far from the urban life that is much sought after by tourists (Figure 1). Gusung Island can also be an option for diving and snorkeling. Fifth, tourism in a destination requires a positive response from the community to receive tourists who enter their area. To assess whether the community is willing to accept tourists or not, the people's hospitality is a reliable measurement indicator. The trend that occurs in Gusung Island is that the people are willing to welcome guests or tourists. Researcher asked permission from the local village coconut before collecting data and communicating with the community. In collecting research data, the community welcomed and provided services with cultural hospitality principles for the local community. It is necessary to implement a management strategy and develop tourism 
potential to encourage Gusung Island as a tourist destination. Implementing this strategy focuses on empowering the community as potential owners and becoming actors in tourism activities.

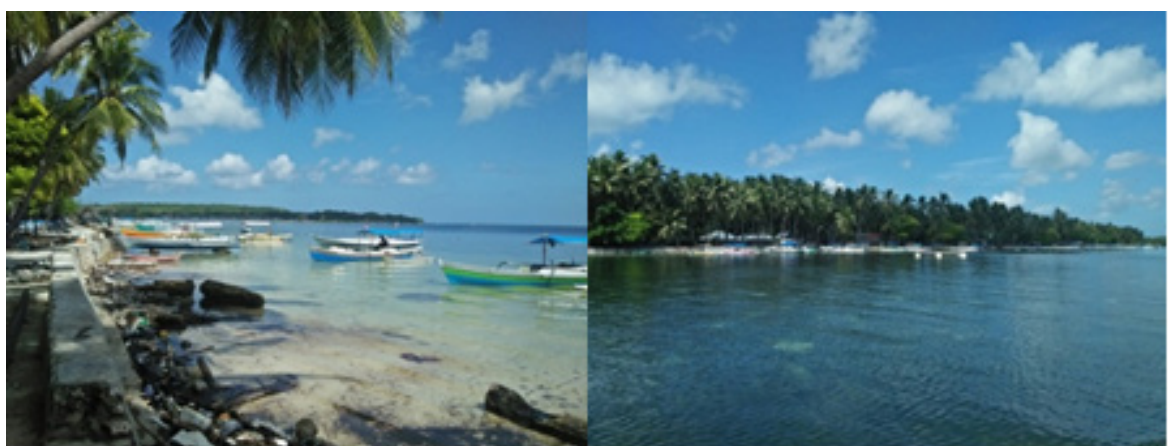

Figure 1.

Gusung Island in Selayar Islands Regency

Source: Researcher's documentation (2019)

\section{Community education in Gusung Island}

In tourism, hospitality plays a fundamental role in regional development; however, good hospitality is not the sole factor that supports the development of a tourism destination. The community needs proper education support on hospitality in the tourism sector. Education in tourism can be carried out by various elements, such as local and village governments and educational institutions. Education should be focused on people who inhabit the area, whether facilitated by outside parties or within the community. Hospitality in the community interprets as an activity in providing education about hospitality to the community. The locals should be knowledgeable in preparing their house for a homestay for tourists' accommodation. They could gain benefit by transforming houses into a homestay for guests of Gusung Island. Diverse types of accommodation will provide various choices for visitors for their stay in Gusung Island. Another form of education is understanding the community about the importance of tourism for community development, and external parties, such as students, can play an essential role in providing this understanding. Community empowerment programs run by higher education can be a priority for community empowerment in the region.

\section{Designing tour packages, packaging, and marketing tourism potential}

The natural potential is not enough to enhance tourism, and promotional efforts are highly required to attract tourists. Promotion is an essential part of marketing tourism products through the use of the internet. The management could promote tourism products through blogs and social media to amplify the delivery of information on Gusung Island to the public.

Designing tourism packages, packaging, and potential marketing is a combination of bottom-up and top-down approaches. The bottom-up approach will directly involve the community before external parties such as the government and industry help the community sell these products. A top-down approach can be implemented with the government as initiator and a facilitator to help the community. This approach requires external support before Gusung Island becomes a sophisticated tourist destination. Through various stakeholders' roles, the local government holds a crucial part in carrying out this strategy. The tourism office has made Gusung Island a target for socialization, education, and assistance for tourism villages.

Assistance in tourism villages requires a high amount of time because the government should involve external organizations, including the community in Benteng City, to encourage tourism villages. The government must provide adequate funds and concentrate on forming community organizations in the tourism sector that will work in the village. In addition, it requires the involvement of external parties, for example, government and educational institutions, to provide socialization and education to the public regarding tourism, hospitality, and tourism destination management. 
Informants stated that many community members could make the traditional cake; however, they do not understand how to market their food. Marketing tourism products is challenging for people on Gusung Island. It requires suitable marketing strategies, one of which is the packaging of traditional food products. Their traditional cake product is known as Tilobang, a home-made pastry produced by the community. An informant revealed:

"We have much potential in our area, such as mangroves, caves, snorkeling locations. We hope there are stalls, lodging, gazebos, small and medium creative industries center, and managing all facilities well. However, only a few people know this potential. If everything is well-managed, many tourists will come to this area. The lack of marketing constrains us. Because only a few guests come to this place, small businesses hardly survive."

Weak marketing is a challenge for people, even when they can create traditional food products; however, some traditional cakes have even been sent to Jakarta. It indicates that there is potential in improving the community's economy through traditional food businesses. There is an inseparable relation between visitors and community businesses. Informants at the focus-group discussion revealed that community empowerment through small and medium-sized enterprises depends on the number of visitors. Conversely, the number of visitors is also inseparable from the availability of various facilities at tourist destinations, such as homestays, community stalls, and various other supporting facilities. Thus, Gusung Island requires the main attraction that stands out to invite tourists.

\section{The role of the working group and sustainable tourism}

An area can be developed into a sophisticated tourism destination with a community focused on developing tourism potential. In several Indonesia destinations, tourist destinations gained popularity from the community or village members in a forum or organization, known as Tourism Awareness Group or Kelompok Sadar Wisata (hereafter called Pokdarwis). For example, Wakatobi District in Southeast Sulawesi Province had succeeded in developing its tourism potential. The area manages by Pokdarwis, whose members are youth and community members in an area. Managing tourism destination is based on principles of Destination Management Organization (DMO). DMO is a strategy to empower active communities in managing tourism potential. The principles are demonstrated in the Nglanggeran Tourism Village in Yogyakarta, where the role of Pokdarwis is the primary key in developing Nglanggeran Tourism Village.

A government organization institutionally manages Gusung Island. The village government consists of various social apparatus, namely hamlet and neighborhood; however, the local government has not prioritized tourism development. Even though they realize that Gusung Island has tourism potential, tourism does not seem to be a strategic alternative for community building. This study recommends the importance of tourism institutions or organizations to facilitate the community to manage tourism potential. Strengthening tourism institutions is aimed to create Pokdarwis or other community organizations facilitated by local or village governments. Gusung Island requires a public understanding of the essence and benefits of tourism, and to reach the community as a whole; community organizations act as facilitators and tourism to help the community. Researcher interviewed a member of the Gusung Island community's Group. According to the informant, the community has now experienced an increase in the economic situation because they owned tools to garner fish in the sea, known as kerambah, which generate decent results to support their families. Thus, an existing community focused on fish and marines, yet a tourism community has not yet been established. Community institutions in the tourism sector are urgently needed to encourage people to manage tourism potential on Gusung Island.

The working group at the village level is part of the village-owned enterprise. Village-owned enterprises on Gusung Island manage kerambah as their production tools; however, community cooperation activities are somewhat challenging to perform, especially regarding waste management. The existing workgroup needs to maximize its role in encouraging the community in its work unit. Waste on Gusung Island is a fundamental problem that hinders coastal areas with white sand beaches. 
The working group should be the mediator in the waste management process in Gusung Island. In other words, institutional strengthening shows by optimizing roles and functions and community groups to encourage people to be involved in community activities.

Gusung Island working group expected to preserve sustainable tourism in the area; however, they face the challenge of fishing communities that use plastic to catch fish. They wrap sand in plastic and make it as bait. The method produces plastic waste, even when they occur in a thin form. The continuous use of plastic could produce unrecyclable waste in the sea. The situation negatively impacts the environmental sustainability of Gusung Island and the surrounding marine areas. The waste problem is a fundamental challenge for the Gusung Island area. Trash scattered on the island, and the coastal area is widely covered with rubbish, consignments, and plastic waste. Sustainable tourism implies an environmental conservation approach. Tourists need a clean environment, and community activities are needed to preserve their environment. Although plastic is the fishers and believed by them to be an effective way of making bait, these methods need to be avoided. Working groups can convince the community to preserve the environment and find solutions or other ways that fishers can catch fish. Murphy's community approach and ecological approach can be used to implement the importance of community empowerment, especially on Gusung Island.

\section{Conclusion}

This research has outlined the opportunities and potentials of Gusung Island to become a leading tourist destination in Indonesia. Even though an area has tourism potential, a strategy is needed to achieve tourism development goals. Gusung Island is an example of a tourist destination that requires attention from the local government and its people to manage its tourism potential. The tourism industry (for example, travel agencies or agents) to create tour packages to Gusung Island is needed as a method to attract tourists. In addition, the tourism potential management strategy is inseparable from the community as actors and managers of the tourism destination. This research has recommended three possible approaches as strategies to help empower communities through tourism activities.

The marine community of Gusung Island can be an option for tour packages. The marine life of the community needs to be supported by the availability of tourism products and other supporting factors, for example, waste management, especially in coastal areas, the availability of lodging in the form of homestays, small and medium-sized enterprises that managed by the community and the readiness of the community to manage all the potentials of Gusung Island. Even though community organizations on Gusung Island, groups or organizations specializing in carrying out tourism potential development activities or programs are needed, the existence of a working group on Gusung Island can realize the implementation of sustainable tourism. The working group will help realize community empowerment following community values and involve various community groups and environmental preservation. This research concluded that, although an island has tourism potential, it still requires efforts or joint steps with various components of society, both internally and externally, to identify, manage, promote, and utilize the existing potential to benefit the destination community itself.

\section{Acknowledgements}

Researcher would like to thank Politeknik Pariwisata Makassar, South Sulawesi for research grant in financial year 2019.

\section{References}

Agrusa J \& Albieri G (2011) Community Empowered Tourism Development: A Case Study. In: Laws E et al. (eds). Tourist Destination Governance: Practice, Theory and Issues. Cambridge: CABI.

Altinay L\& Paraskevas A(2008) Planning Research in Hospitality and Tourism. Oxford: Butterworth-Heinemann.

Caalders J (2000) Tourism in Friesland: A Network Approach. In: Richards G \& Hall D (eds). Tourism and Sustainable Community Development. London: Routledge. 
Clarke A \& Raffay A ( 2011) The Introduction of Tourism Destination Management Organisations in Hungary: Top-Down Meets Bottom-Up. In: Dredge D \& Jenkins J (eds). Stories of Practice: Tourism Policy and Planning. Farnham. Lismore: Southern Cross University.

Dahles H (2000) Tourism, Small Enterprises and Community Development. In: Richards G \& Hall D (eds). Tourism and Sustainable Community Development. London: Routledge.

Hall D (2000) Identity, Community and Sustainability: Prospects For Rural Tourism in Albania. In G. Richards \& D Hall (eds.) Tourism and Sustainable Community Development. London: Routledge. 48-59.

Hesse-Biber SN \& Leavy P (2011) The Practice of Qualitative Research. California: SAGE.

Junaid I (2016) Analisis data kualitatif dalam penelitian pariwisata. Jurnal Kepariwisataan 10 (1):59-74.

Junaid I \& Nur Fauziah A (2018) The carrying capacity for the development of marine ecotourism. Masyarakat, Kebudayaan dan Politik 31 (2):190-200. https://doi.org/10.20473/mkp.V31I2 2018.190-200.

Jurowski C (2011) Tourism Development and Destination Community Residents. In: Wanng Y \& Pizam A (eds). Destination Marketing and Management: Theories and Applications. London: CABI.

Kusumawardani E \& Septiarti SW (2019) Youth involvement: Empowerment effort through childfriendly village. Masyarakat, Kebudayaan dan Politik 32 (2):209-216. https://doi.org/10.204 73/mkp.V32I22019.209-216.

Martono E \& Muhamad (2017) Pemberdayaan masyarakat melalui pengembangan desa wisata dan implikasinya terhadap ketahanan sosial budaya wilayah (Studi di Desa Wisata Penglipuran Bali). Jurnal Ketahanan Nasional 23(1):1-16. https://doi.org/10.22146/jkn.18006.

Mertha IW, Wiarti LY, \& Suasapha A (2018) Stakeholders: Peran dan kendala pelibatannya dalam pengembangan desa wisata di Bali. Jurnal Kepariwisataan 17 (2):15-23.

Moscardo G(2008) Community Capacity Building: An Emerging Challenge for Tourism Development. In: Moscardo G (ed). Building Community Capacity for Tourism Development. Wallingford: CABI.

Murphy PE (1985) Tourism: A Community Approach. New York: Routledge.

Obenour WL \& Cooper N (2013) Tourism Planning and Power Within Micropolitan Community Development. In: Phillips R \& Roberts S (eds). Tourism, Planning and Community Development. New York: Routledge.

Putra AS (2013) Pola kemitraan pariwisata dalam manajemen atraksi Desa Wisata Pampang Kota Samarinda. Jurnal Nasional Pariwisata 5 (3):189-200.

Priyanto \& Safitri D (2016) Pengembangan potensi desa wisata berbasis budaya: Tinjauan terhadap desa wisata di Jawa Tengah. Jurnal Vokasi Indonesia 4 (1):77-84.

Ratu C \& Adikampana M (2016) Strategi pemasaran Desa Wisata Blimbingsari Kabupaten Jembrana. Jurnal Destinasi Pariwisata 4:60-67.

Richards G \& Hall D (2000) The Community: A Sustainable Concept in Tourism Development? In: Richards G \& Hall D (eds). Tourism and Sustainable Community Development. London: Routledge.

Riley RW \& Love LL (2000) The state of qualitative tourism research. Annals of Tourism Research 27 (1):164-187.

Rocharungsat P (2008) Community-Based Tourism In Asia. In: Moscardo G (ed). Building Community Capacity For Tourism Development. Wallingford: CABI.

Strzelecka M \& Wicks BE (2013) Engaging Residents in Planning for Sustainable Rural-Nature Tourism in Post-Communist Poland. In: Phillips \& Roberts S (eds).Tourism, Planning, and Community Development. New York: Routledge.

Syafi'I MD \& Suwandono D (2015) Perencanaan desa wisata dengan pendekatan konsep community based tourism (CBT) di Desa Bedono, Kecamatan Sayung, Kabupaten Demak. Jurnal Ruang $1(2): 51-60$.

Yulianie F (2015) Partisipasi dan pemberdayaan masyarakat dalam pengelolaan daya tarik wisata "Rice Terrace" Ceking, Gianyar, Bali. Jurnal Master Pariwisata 2 (1):165-184.

Yin RK (2011) Qualitative Research from Start to Finish. New York: The Guilford Press. 